UDC 620.197.2

Doi: $10.31772 / 2587-6066-2020-21-1-115-124$

For citation: Mikheev A. E., Girn A. V., Ravodina D. V., Elizar'eva I. G. The influence of prefinishing operations at titanium alloys on the characteristics of mao coatings. Siberian Journal of Science and Technology. 2020, Vol. 21, No. 1, P. 115-124. Doi: 10.31772/2587-6066-2020-21-1-115-124

Для цитирования: Влияние предварительной подготовки поверхности титановых сплавов на характеристики МДО покрытий / А. Е. Михеев, А. В. Гирн, Д. В. Раводина, И. Г. Елизарьева // Сибирский журнал науки и технологий. 2020. Т. 21, № 1. С. 115-124. Doi: 10.31772/2587-6066-2020-21-1-115-124

\title{
THE INFLUENCE OF PREFINISHING OPERATIONS AT TITANIUM ALLOYS ON THE CHARACTERISTICS OF MAO COATINGS
}

\author{
A. E. Mikheev, A. V. Girn, D. V. Ravodina, I. G. Elizar'eva \\ Reshetnev Siberian State University of Science and Technology \\ 31, Krasnoyarsky Rabochy Av., Krasnoyarsk, 660037, Russian Federation \\ E-mail: michla@mail.ru
}

Improving the reliability, service life and operational safety of titanium alloy structures exposed to thermal, chemical and mechanical stresses can be achieved by applying various protective coatings.

One of the effective methods of protecting such alloys is the formation on their surface of oxide coatings that are resistant to external factors. Of great interest from this point of view is the method of micro-arc oxidation (MAO), which allows one to obtain multifunctional ceramic-like oxide coatings with unique properties. Such coatings can be used to create a durable heat and electrical insulating layer on parts, protect surfaces from erosion in high-speed gas flows, corrosion in aggressive environments and wear by friction, to increase the surface emissivity, etc.

This method is well established for the oxidation of aluminum alloys. Despite the fact that the mechanism of coating formation during MAO is the same for aluminum and titanium alloys, there are certain differences in the structure and characteristics of the resulting coating. For example, it is believed that during the MAO treatment of aluminum alloys, preliminary surface preparation is not required and the adhesive strength is comparable with the strength of the substrate material. However, when processing titanium alloys, we noted cases of a significant decrease in adhesive strength. One of the reasons may be the lack of preliminary surface preparation before coating.

Therefore, studies aimed at studying the influence of the method of surface preparation and the resulting roughness on the characteristics of the applied coatings are relevant.

Keywords: micro-arc oxidation, titanium alloys, surface preparation, thickness, adhesive strength, roughness.

\section{ВЛИЯНИЕ ПРЕДВАРИТЕЛЬНОЙ ПОДГОТОВКИ ПОВЕРХНОСТИ ТИТАНОВЫХ СПЛАВОВ НА ХАРАКТЕРИСТИКИ МДО ПОКРЫТИЙ}

\author{
А. Е. Михеев, А. В. Гирн, Д. В. Раводина, И. Г. Елизарьева \\ Сибирский государственный университет науки и технологий имени академика М.Ф. Решетнева \\ Российская Федерация, 660037, г. Красноярск, просп. им. газ. «Красноярский рабочий», 31 \\ E-mail: michla@mail.ru
}

Повышения надежности, ресурса работы и безопасности эксплуатации конструкций из титановых сплавов, подвергающихся воздействию тепловых, химических и механических нагрузок, можно добиться нанесением различных защитных покрытий.

Одним из эффективных методов защчиты таких сплавов является образование на их поверхности устойчивых против воздействия внешних факторов оксидных покрытий. Большой интерес с этой точки зрения представляет метод микродугового оксидирования (МДО), позволяющий получать многофункциональнье керамикоподобные оксидные покрытия с уникальными свойствами. Такие покрытия могут применяться для создания на деталях прочного тепло- и электроизолирующего слоя, защиты поверхностей от эрозии в высокоскоростных газовых потоках, коррозии в агрессивных средах и износа трением, для повышения коэффициента излучения поверхности и т. $n$.

Этот метод хорошо отработан для оксидирования алюминиевых сплавов. Несмотря на то, что механизм образования покрытий при МДО для алюминиевых и титановых сплавов одинаков, существуют определенные различия в структуре и характеристиках полученного покрытия. Например, считается, что при обработке МДО алюминиевых сплавов не требуется предварительная подготовка поверхности и адгезионная прочность 
сопоставима с прочностью материала подложки. Однако при обработке титановых сплавов нами были отмечены случаи значительного снижения адгезионной прочности. Одной из причин может быть отсутствие предварительной подготовки поверхности перед нанесением покрытий.

Поэтому исследования, направленные на изучение влияния способа подготовки поверхности и полученной шероховатости на характеристики нанесенных покрытий, являются актуальными.

Ключевые слова: микродуговое оксидирование, титановые сплавы, подготовка поверхности, толщина, адгезионная прочность, шероховатость.

Introduction. The composition, concentration of electrolyte components and the duration of MAO have a major effect on the characteristics of oxide layers. The essence of MAO is that under the influence of electric current applied between the part located in the electrolyte and the metal cathode (electrolytic cell body or electrode), migrating point micro-arc discharges (MAD) arise on its surface, from the effect of which a ceramic coating is formed on the surface [1-7]. The electrolyte composition for MAO is selected based on the chemical composition of the hardened valve alloy and the function of the coating.

In the MAO process, diffusion, thermal, plasmochemical and electrophysical processes play a significant role. Conventionally, these processes can be divided into several stages, which proceed sequentially or in parallel:

1) chemical interaction between the base material and the forming coating with the electrolyte;

2) electrochemical processes that occur both before ignition of an electric discharge and after its ignition in areas of the treated surface where there is currently no discharge (anodization in aqueous solutions of electrolytes and electrolysis);

3 ) in fact, micro-arc oxidation, which includes the short initial stages of luminescence and sparking and then the main stage of MAD combustion;

4) transition of a micro-arc discharge in an arc discharge after the formation of an MAO coating of a certain thickness.

The voltage at which sparking begins in the electrolyte depends on the composition of the material being processed and the electrolyte. At a small coating thickness, due to the large heat removal, a spark discharge is observed, which with an increase in the film thickness transforms into MAD, and at large thicknesses it transforms into an arc [8-10].

It is reputed that a necessary condition for the occurrence of an electric discharge in an electrolyte is the presence of a gas or vapor-gas layer between the electrolyte and the base metal. Apparently, the discharge during MAO is gas and arises as a result of electric breakdown of vapor-gas "plugs" formed in micro-pores of a porous oxide layer growing on the barrier layer. These plugs are formed during electrolysis processes of the discharge of $\mathrm{H}+$ or $\mathrm{OH}-$ ions and boiling of electrolyte in pore channels [11].

It is generally thought that during MAO treatment of aluminum alloys, preliminary surface preparation is not required and the adhesive strength is comparable with the strength of the substrate material. However, when processing titanium alloys, we noted cases of a significant decrease in adhesive strength. One of the reasons may be the lack of preliminary surface preparation before coating.
Therefore, there is a need to study the effect of preliminary surface preparation on the characteristics of coatings.

Surface preparation can be carried out in many ways, such as: grinding, matting, polishing, tumbling, vibration processing, blast-abrasive treatment, degreasing, etching, activation.

MAO coatings are ceramics of complex composition [12-16]. The coating during micro-arc oxidation is formed due to the oxidation of the metal surface and oxide and hydroxide forms of this metal are formed. On the other hand, the coating grows due to the inclusion of electrolyte cells in its composition. Electrolyte elements enter the coating in the form of salts, oxides and hydroxides of complex composition. If necessary, the MAO technology allows you to enter into the coating any desired chemical element.

The main characteristics of the resulting coatings include the following parameters: adhesion, coating thickness, porosity, wear resistance, etc.

Experimental procedure. VT 6/BT 6 titanium alloy with a thickness of $3 \mathrm{~mm}$, dimensions $50 \times 40 \mathrm{~mm}$ was used for the manufacture of samples. The composition and characteristics of VT 6/BT 6 are presented in tab. 1. When choosing the material, it was assumed that this alloy is widely used for the manufacture of a significant range of parts in mechanical engineering, the manufacture of aircraft and spacecraft, fasteners and threaded parts, etc.

As already mentioned above, the speciation, the concentration of electrolyte components, and the duration of MAO have the greatest effect on the adhesion, thickness, structure and phase composition of oxide layers. The effect of surface pretreatment on the characteristics of the applied coatings is not well investigated.

Preliminary experimental studies were carried out to select the modes of MAO treatment. The samples were processed in an experimental MAO installation operating on a three-phase alternating current network of $380 \mathrm{~V}$ and a frequency of $50 \mathrm{~Hz}$. The current source was the IAT-T2/ИAТ-T2 transformer (asymmetric current source).

As a result of a literature review and scientific patent search, several electrolyte compositions of interest to us were identified [17-19]. The formation of oxide coatings on products from titanium-based alloys was carried out in solutions of sodium hydrogen phosphate and sodium silicate with the addition of potassium hydroxide, which were prepared by dissolving the calculated amount of chemical reagents in distilled water (tab. 2).

During the experiment it was found that with an increase in the ratio of the cathodic and anodic components of the current strength, the thickness of the oxide layer decreases (fig. 1) and the adhesive strength of the coating increases (fig. 2). 
Table 1

VT 6/BT 6 speciation and characteristics

\begin{tabular}{|c|c|c|c|c|c|c|c|c|c|c|}
\hline \multicolumn{5}{|c|}{ Grade } & \multicolumn{6}{|c|}{ VT 6/BT 6} \\
\hline \multicolumn{5}{|c|}{ Classification: } & \multicolumn{6}{|c|}{ titanium wrought alloy } \\
\hline \multicolumn{11}{|c|}{ Chemical composition in \% for grade VT1-0/BT1-0 GOST 19807-91 } \\
\hline $\mathrm{Fe}$ & $\mathrm{C}$ & $\mathrm{Si}$ & V & $\mathrm{N}$ & $\mathrm{Ti}$ & $\mathrm{Al}$ & $\mathrm{Zr}$ & $\mathrm{O}$ & $\mathrm{H}$ & Impurities \\
\hline $\begin{array}{l}\text { to } \\
0.6\end{array}$ & to 0.1 & to 0.1 & $3.5-5.3$ & to 0.05 & $86.45-90.9$ & $5.3-6.8$ & to 0.3 & to 0.2 & to 0.015 & others 0.3 \\
\hline \multicolumn{5}{|c|}{ VT 6/BT 6 hardness after quenching and aging } & \multicolumn{6}{|c|}{ HB $10^{-1}=293-361 \mathrm{MPa}$} \\
\hline \multicolumn{5}{|c|}{ VT 6/BT 6 hardness after annealing } & \multicolumn{6}{|c|}{$\mathrm{HB} 10^{-1}=255-341 \mathrm{MPa}$} \\
\hline
\end{tabular}

The speciation and concentration of electrolytes, processing modes

Table 2

\begin{tabular}{|c|c|c|c|c|c|}
\hline $\begin{array}{l}\text { Number of } \\
\text { electrolyte }\end{array}$ & $\begin{array}{l}\text { Speciation of } \\
\text { electrolyte }\end{array}$ & Concentration, $\mathrm{g} / 1$ & Alloy & $\begin{array}{l}\text { The ratio of the cathode } \\
\text { and anodic components of } \\
\text { the current (Ік/Іа) }\end{array}$ & $\begin{array}{l}\text { Current density, } \\
\text { j A } / \mathrm{dm}^{2}\end{array}$ \\
\hline 1 & $\mathrm{Na}_{2} \mathrm{HPO}_{4}$ & 60 & \multirow[t]{3}{*}{ VT 6/BT 6} & \multirow[t]{3}{*}{0,$8 ; 1 ; 1,2$} & \multirow[t]{3}{*}{20,30} \\
\hline \multirow[t]{2}{*}{2} & $\mathrm{KOH}$ & 30 & & & \\
\hline & $\mathrm{Na}_{2} \mathrm{SiO}_{3}$ & 50 & & & \\
\hline
\end{tabular}

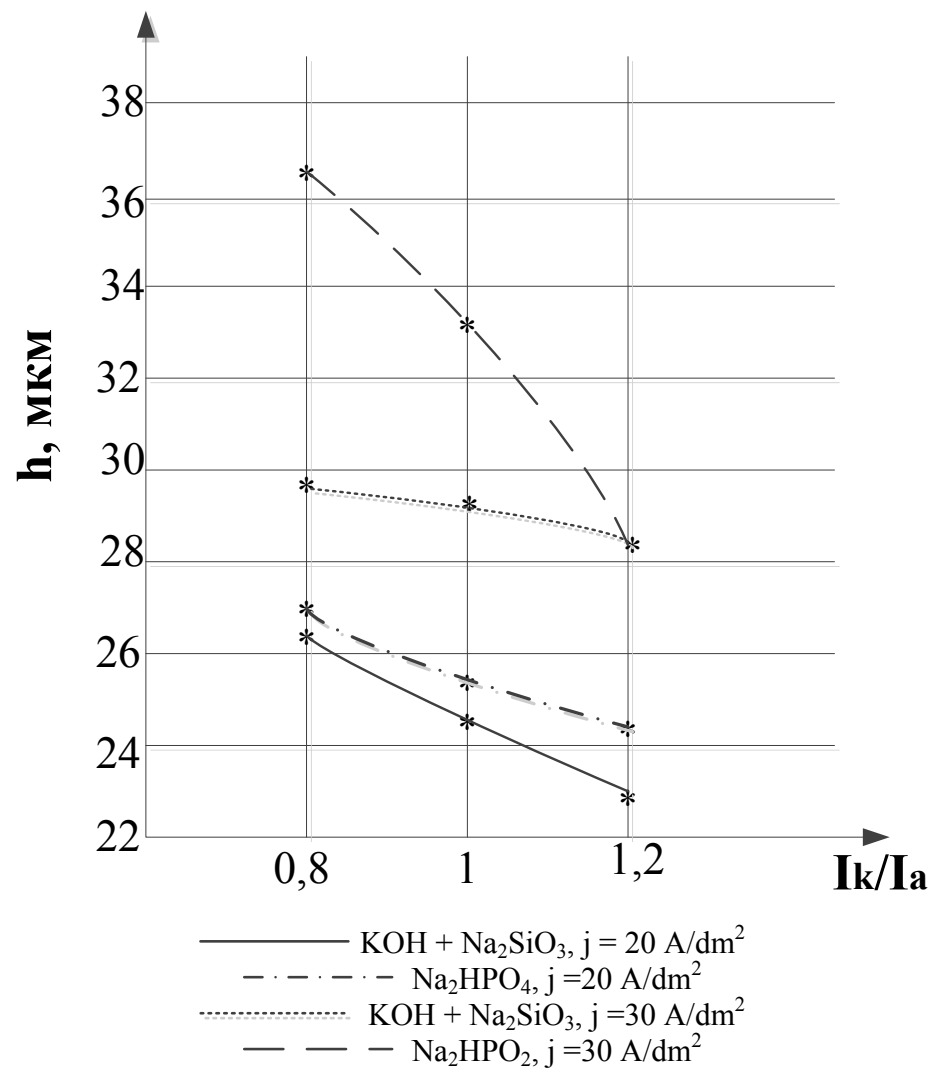

Fig. 1. Dependence of the coating thickness on the ratio of the cathode and anode component of the current

Рис. 1. Зависимость толщины покрытия от отношения катодной и анодной составляющей силы тока 


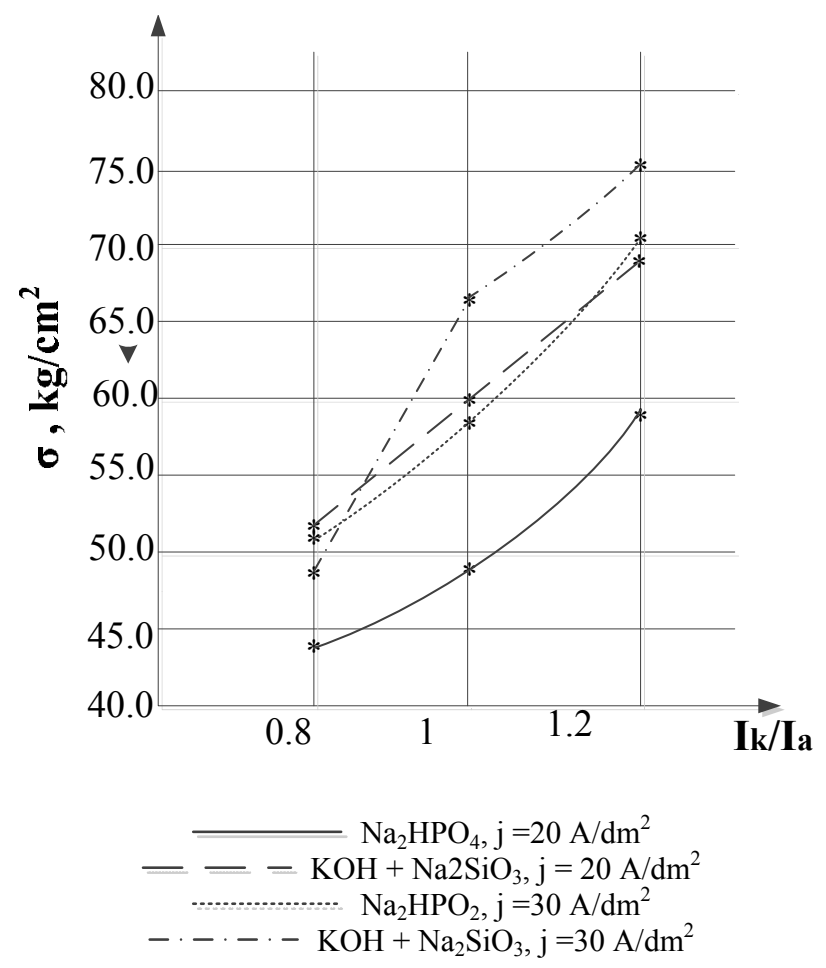

Fig. 2. Test results for adhesive strength of the coating

Рис. 2. Результаты испытаний на адгезионную прочность покрытия

MAO processing mode

\begin{tabular}{|l|c|c|}
\hline \multicolumn{1}{|c|}{ Parameter } & Notation & Value \\
\hline Run time & $\mathrm{t}$ & $10 \mathrm{~min}$ \\
\hline Current density & $\mathrm{J}$ & $20 \mathrm{~A} / \mathrm{dm}^{2}$ \\
\hline The ratio of the cathode and anodic component of the current & $\mathrm{I}_{\mathrm{k}} / \mathrm{I}_{\mathrm{a}}$ & 1.2 \\
\hline \multirow{2}{*}{ Current } & $\mathrm{I}_{\mathrm{K}},-$ & 5.2 \\
\hline \multirow{3}{*}{ Electrolyte compositions } & $\mathrm{I}_{\mathrm{a}},+$ & 4.4 \\
\cline { 2 - 3 } & № 1 & $\mathrm{Na}_{2} \mathrm{HPO}_{4}$ \\
\cline { 2 - 3 } & \multirow{2}{*}{ № 2 } & $\mathrm{KOH}$ \\
\cline { 2 - 3 } & $\mathrm{Na}_{2} \mathrm{SiO}_{3}$ \\
\hline
\end{tabular}

It was also revealed that when processing with a current density of $\mathrm{J}=30 \mathrm{~A} / \mathrm{dm}^{2}$ in the aqueous $\mathrm{Na}_{2} \mathrm{HPO}_{4}$ solution, the samples burn up, and in the silicate-alkaline electrolyte $\left(\mathrm{KOH}+\mathrm{Na}_{2} \mathrm{SiO}_{3}\right)$ the solution boils. Based on this, a further mode of MAO processing was selected, which is presented in tab. 3 .

A methodology for conducting experimental studies was developed to determine the dependence of coating properties on preliminary surface preparation.

As a method of surface preparation, the machining of samples on sanding paper of various grit sizes used on a Struers LaboPol-1 grinding and polishing machine and a sandblasting machine with corundum was chosen.

Acetone (GOST 2768-84) was used for degreasing.

As a result, the roughness data of the processed samples were obtained, presented in tab. 4 and in fig. 3 and 4 . Roughness measurement was carried out with a TR110 profilometer, which meets the requirements of ISO and DIN standards.

The prepared samples were coated with MAO coatings. The thickness of the resulting coating was determined using a TT-260 thickness gauge according to GOST 9.302. Ten measurements were performed on one sample. The value of the coating thickness was determined as the arithmetic mean between ten measurements on a segment of $5 \mathrm{~mm}$ in one sample. The relative error of the method is $\pm 0.8 \mu \mathrm{m}$ for coatings up to $25 \mu \mathrm{m}$ and $10 \%$ for coatings with a thickness exceeding $25 \mu \mathrm{m}$ (tab. 5, fig. 5, 6). The results of measurements of the thickness of the coatings are presented in tab. 5 and fig. 5, 6 .

The graphs show that in the overall picture, with a decrease in surface roughness, the coating thickness increases. This can be explained by the fact that with an increase in surface cleanliness, the time to reach the MAO treatment mode decreases. 
Surface preparation and sample roughness

\begin{tabular}{|c|c|c|c|c|}
\hline $\begin{array}{c}\text { Number } \\
\text { of sample }\end{array}$ & Process & Grain size, microns & Ra, microns & Roughness grade \\
\hline 1.1 & Degrease cleansing treatment & - & 1.02 & 7 \\
\hline 1.2 & P80 & $200 \ldots 250$ & 0.8 & 7 \\
\hline 1.3 & P180 & $63 \ldots 80$ & 0.675 & 7 \\
\hline 1.4 & P320 & $40 \ldots 50$ & 0.505 & 9 \\
\hline 1.5 & P600 & $20 \ldots 28$ & 0.28 & 9 \\
\hline 1.6 & P1000 & $14 \ldots 20$ & 0.21 & 10 \\
\hline 1.7 & P1500 & $7 \ldots 10$ & 0.175 & 10 \\
\hline 1.8 & P2500 & $3 \ldots 5$ & 0.135 & 4 \\
\hline
\end{tabular}

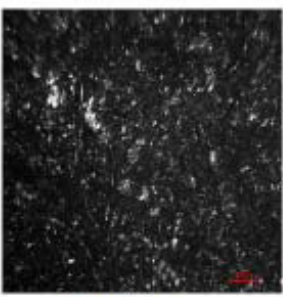

Sandblast

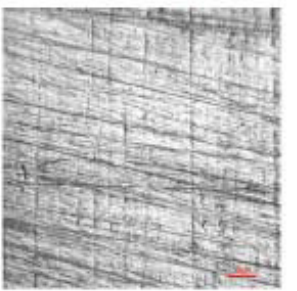

P320

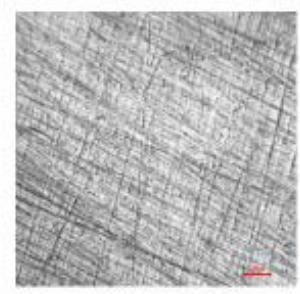

P600

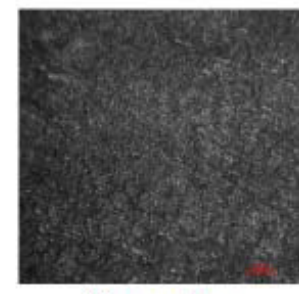

Degreasing

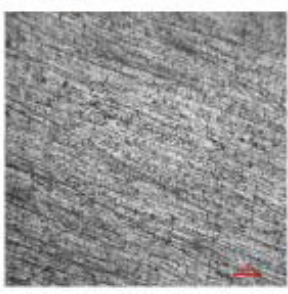

P1000

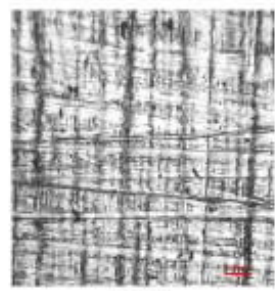

P80

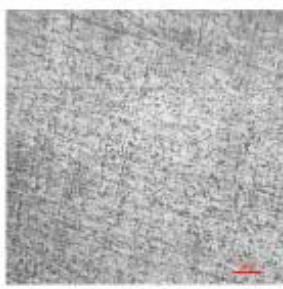

P1500

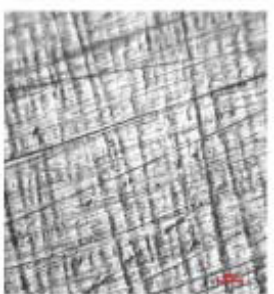

P180

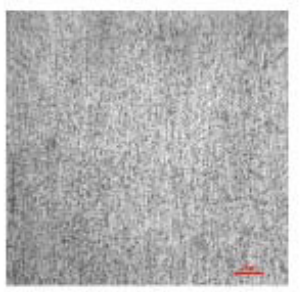

P2500

Fig. 3. Appearance of the surface of the processed samples

Рис. 3. Внешний вид поверхности обработанных образцов

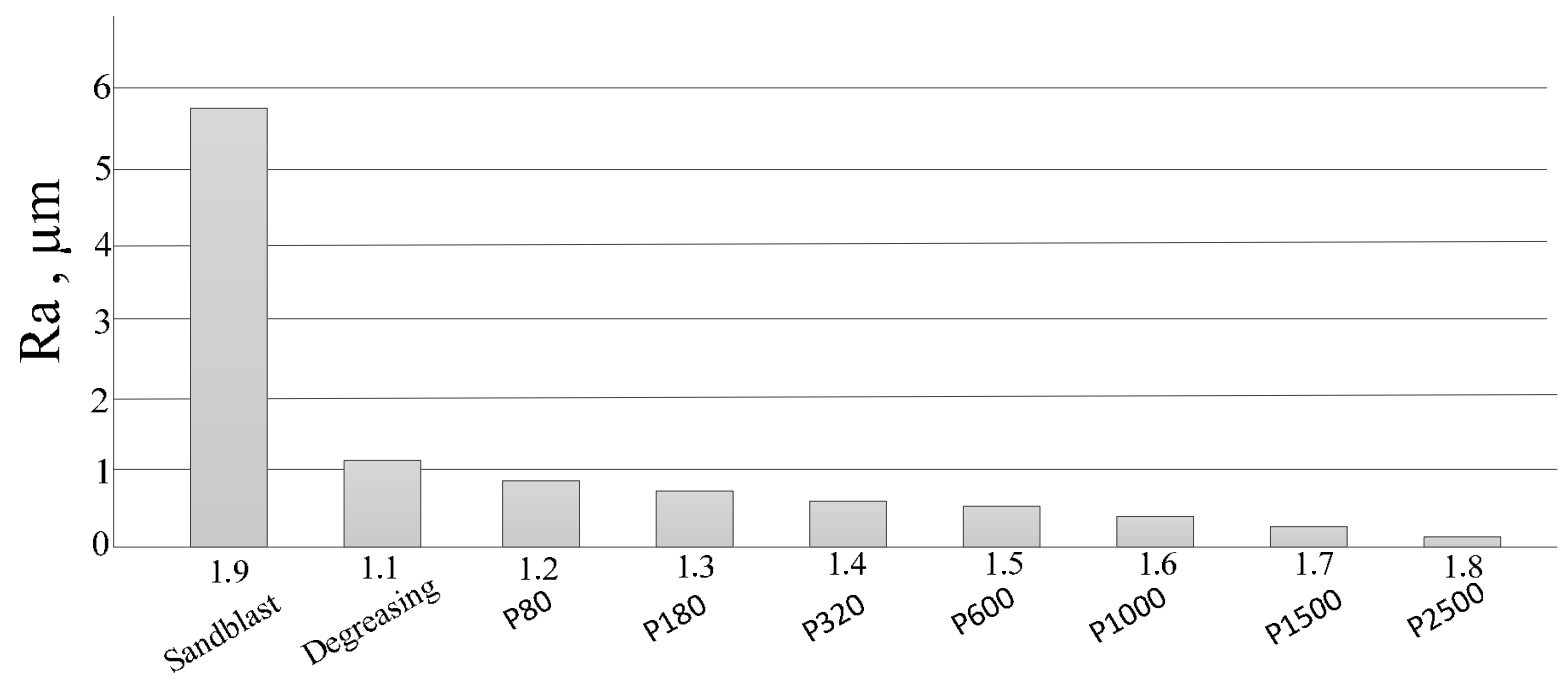

Sample number and surface preparation method

Fig. 4. Surface roughness of samples

Рис. 4. Шероховатость поверхности образцов 
Coating thickness

Table 5

\begin{tabular}{|c|c|c|c|c|c|c|c|c|c|c|}
\hline \multicolumn{10}{|c|}{ Phosphate electrolyte $\left(\mathrm{Na}_{2} \mathrm{HPO}_{4}\right)$} \\
\hline $\begin{array}{c}\text { Number of sample } \\
\text { and roughness } \\
(\mathrm{Ra}, \mu \mathrm{m})\end{array}$ & $\begin{array}{c}1.1 \\
(\mathrm{Ra}=1.02)\end{array}$ & $\begin{array}{c}1.2 \\
(\mathrm{Ra}=0.8)\end{array}$ & $\begin{array}{c}1.3 \\
(\mathrm{Ra}=0.675)\end{array}$ & $\begin{array}{c}1.4 \\
\mathrm{Ra}=0.505)\end{array}$ & $\begin{array}{c}1.5 \\
(\mathrm{Ra}=0.28)\end{array}$ & $\begin{array}{c}1.6 \\
(\mathrm{Ra}=0.21)\end{array}$ & $\begin{array}{c}1.7 \\
(\mathrm{Ra}=0.175)\end{array}$ & $\begin{array}{c}1.8 \\
(\mathrm{Ra}=0.135)\end{array}$ & $\begin{array}{c}1.9 \\
(\mathrm{Ra}=5.64)\end{array}$ \\
\hline $\mathrm{h}, \mu \mathrm{m}$ & 27.77 & 28.86 & 28.36 & 28.85 & 28.8 & 28.45 & 29.37 & 30.16 & 31.73 \\
\hline \multicolumn{7}{|c|}{ Silicate-alkaline electrolyte $\left(\mathrm{KOH}+\mathrm{Na}_{2} \mathrm{SiO}_{3}\right)$} \\
\begin{tabular}{c|c|c|c|c|c|c|c|c|}
2 \\
$\begin{array}{c}\text { Number of sample } \\
\text { and roughness } \\
(\mathrm{Ra}, \mu \mathrm{m})\end{array}$
\end{tabular} & $\begin{array}{c}2.1 \\
\mathrm{Ra}=1.02)\end{array}$ & $\begin{array}{c}2.2 \\
(\mathrm{Ra}=0.8)\end{array}$ & $\begin{array}{c}2.3 \\
(\mathrm{Ra}=0.675)\end{array}$ & $\begin{array}{c}2.4 \\
\mathrm{Ra}=0.505)\end{array}$ & $\begin{array}{c}2.5 \\
(\mathrm{Ra}=0.28)\end{array}$ & $\begin{array}{c}2.6 \\
(\mathrm{Ra}=0.21)\end{array}$ & $\begin{array}{c}2.7 \\
(\mathrm{Ra}=0.175)\end{array}$ & $\begin{array}{c}2.8 \\
(\mathrm{Ra}=0.135)\end{array}$ & $\begin{array}{c}2.9 \\
(\mathrm{Ra}=5.64)\end{array}$ \\
\hline $\mathrm{h}, \mu \mathrm{m}$ & 20.01 & 30.45 & 31.45 & 31.78 & 32.1 & 32.32 & 32.24 & 32.47 & 21.38 \\
\hline
\end{tabular}

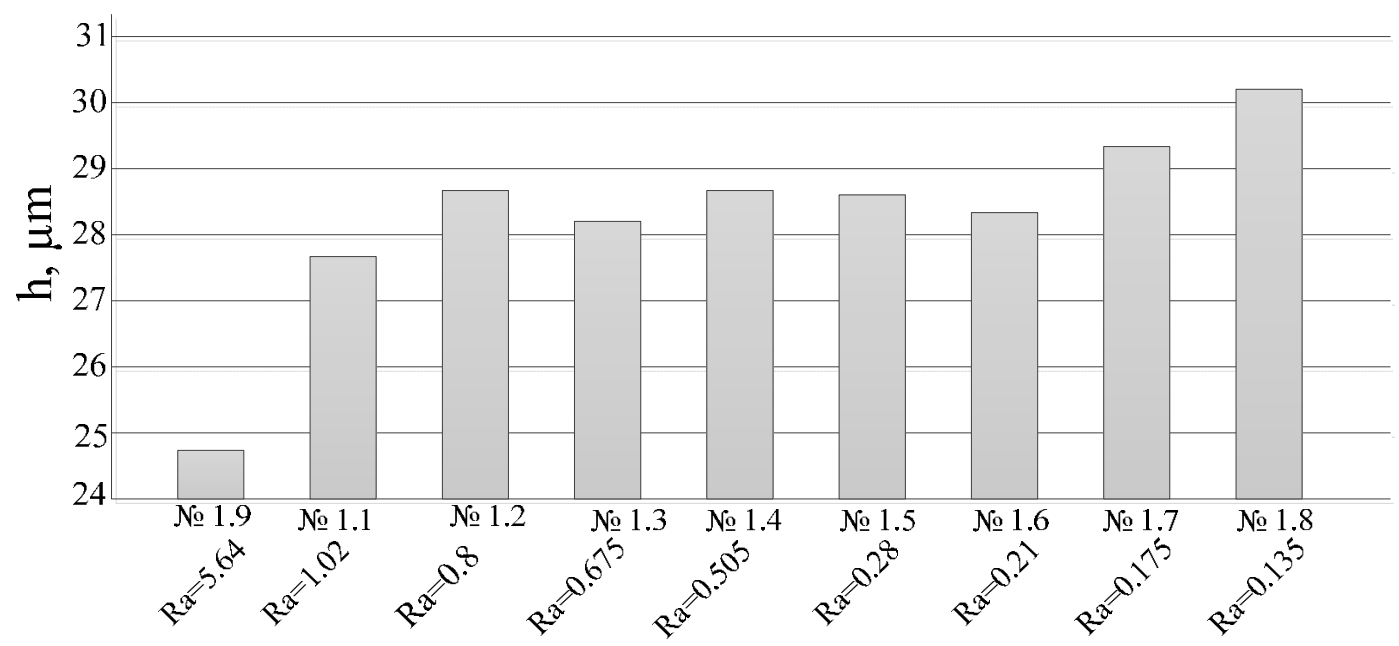

Sample number and roughness $\mathrm{Ra}, \mu \mathrm{m}$

Fig. 5. Roughness dependence of the thickness of coatings obtained in an aqueous solution of $\mathrm{Na}_{2} \mathrm{HPO}_{4}$

Рис. 5. Зависимость толщины покрытий, полученных в водном растворе $\mathrm{Na}_{2} \mathrm{HPO}_{4}$, от шероховатости

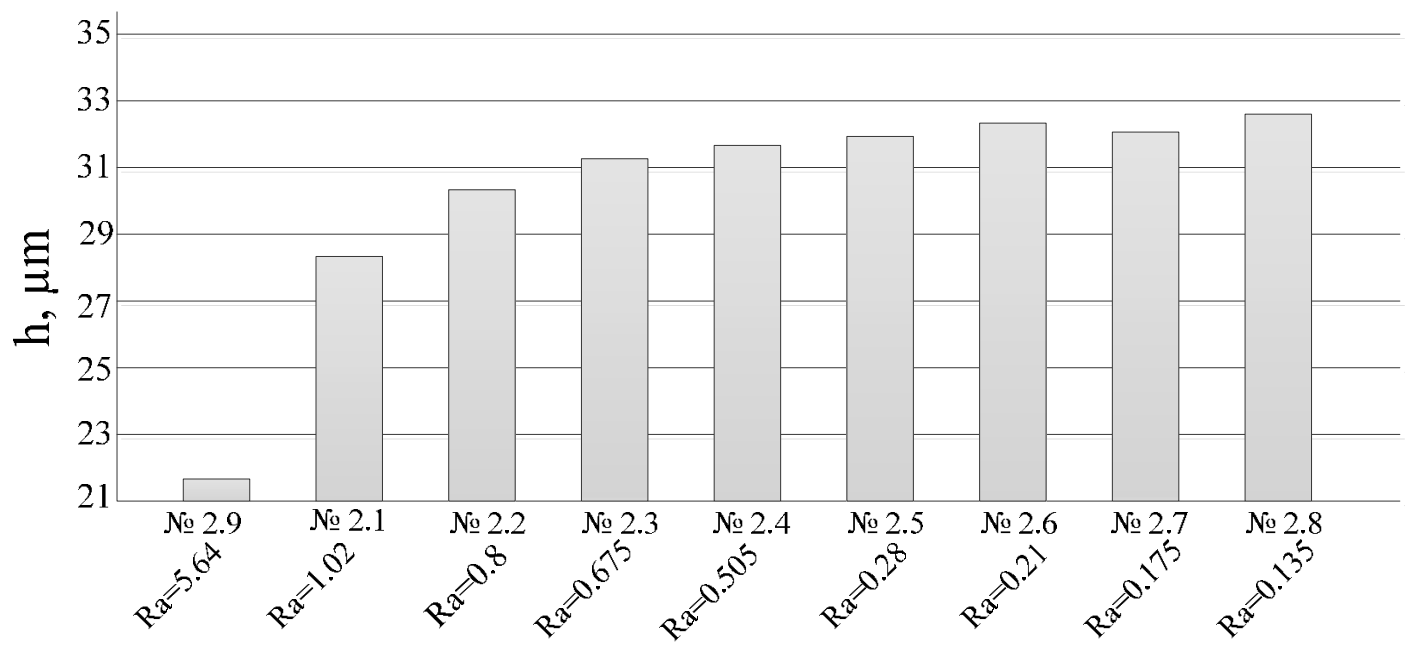

Sample number and roughness $\mathrm{Ra}, \mu \mathrm{m}$

Fig. 6. Roughness dependence of the thickness of coatings obtained in an aqueous solution of $\mathrm{KOH}+\mathrm{Na}_{2} \mathrm{SiO}_{3}$

Рис. 6. Зависимость толщины покрытий, полученных в водном растворе $\mathrm{KOH}+\mathrm{Na}_{2} \mathrm{SiO}_{3}$, от шероховатости 
Determination of adhesive strength. The adhesion strength was determined by the separation method according to GOST 209-75 [20] (adhesive method, VK-3/ BK-3 glue) as the ratio of the force (up to $10 \mathrm{kN}$ ) at which separation occurs from the counter sample glued with an oxide coating to the cross-sectional area $\left(49 \mathrm{~cm}^{2}\right)$.

To measure the adhesion strength of the coating on a EUROTEST T-50 tensile testing machine (fig. 7) suspension equipment was developed and manufactured, as shown in fig. 8 .

Fig. 9 shows the results of the dependence of the adhesion strength of coatings to the base obtained in the $\mathrm{Na} 2 \mathrm{HPO} 4$ electrolyte with various pretreatment methods. The adhesion strength of the coating on the sample with $\mathrm{Ra}=5.64 \mu \mathrm{m}$ prepared by the sand blasting device turned out to be maximum, but crack occurred in gluing area, i. e. true strength is not established. The remaining samples had a separation of the coating from the base. Coating adhesion decreases with a decrease in surface roughness.

Fig. 10 shows the results of the dependence of the adhesion strength of the coatings to the base obtained in the $\mathrm{KOH}+\mathrm{KOH}+\mathrm{Na}_{2} \mathrm{SiO}_{3}$ electrolyte with various pretreatment methods. In all samples, crack occurred in gluing area.

It is related to the fact that adhesive strength VK $3 / \mathrm{BK} 3=40 \mathrm{~kg} / \mathrm{cm}^{2}$, and the experimental sample area is $\mathrm{S}=2 \mathrm{~cm}^{2}$, based on this, the adhesion of the coating to the sample does not exceed $80 \mathrm{~kg} / \mathrm{cm}^{2}$, which corresponds to the adhesive strength.

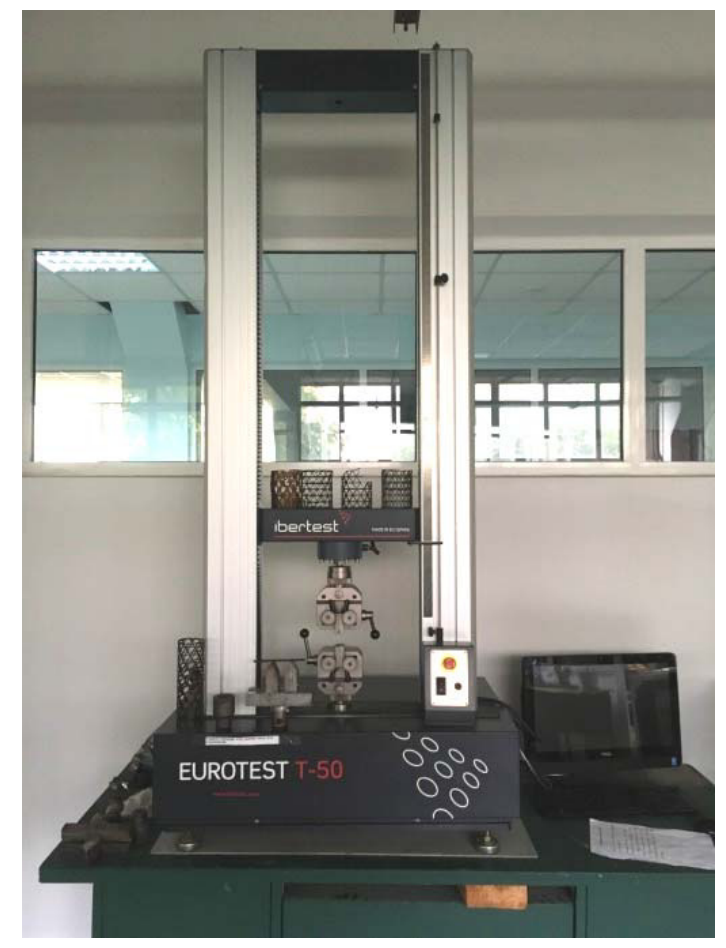

Fig. 7. Bursting machine EUROTEST T-50

Рис. 7. Разрывная машина EUROTEST T-50
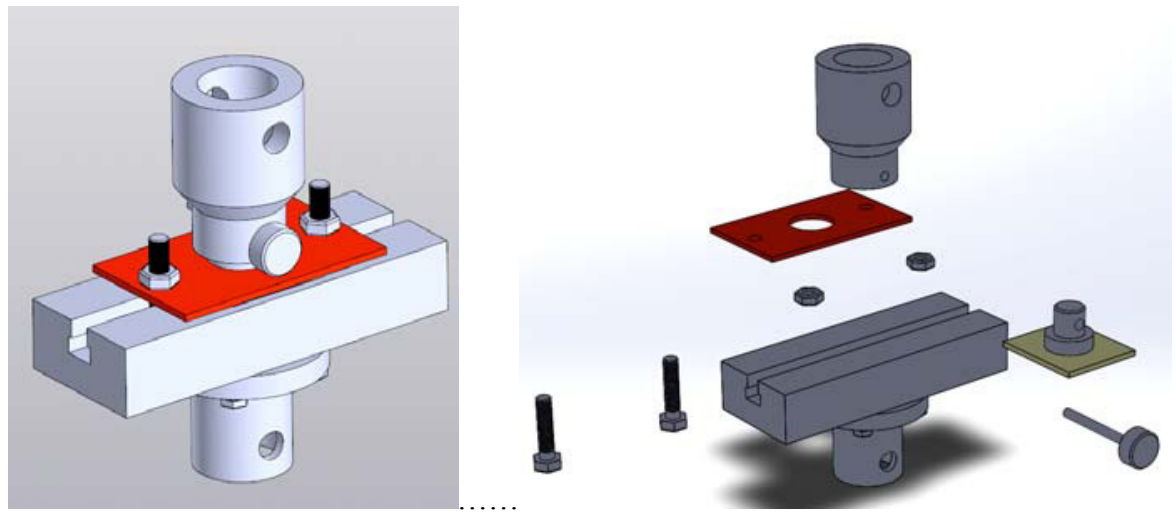

Fig. 8. 3D model of bolt clamp

Рис. 8. 3D модель зажима болтового 


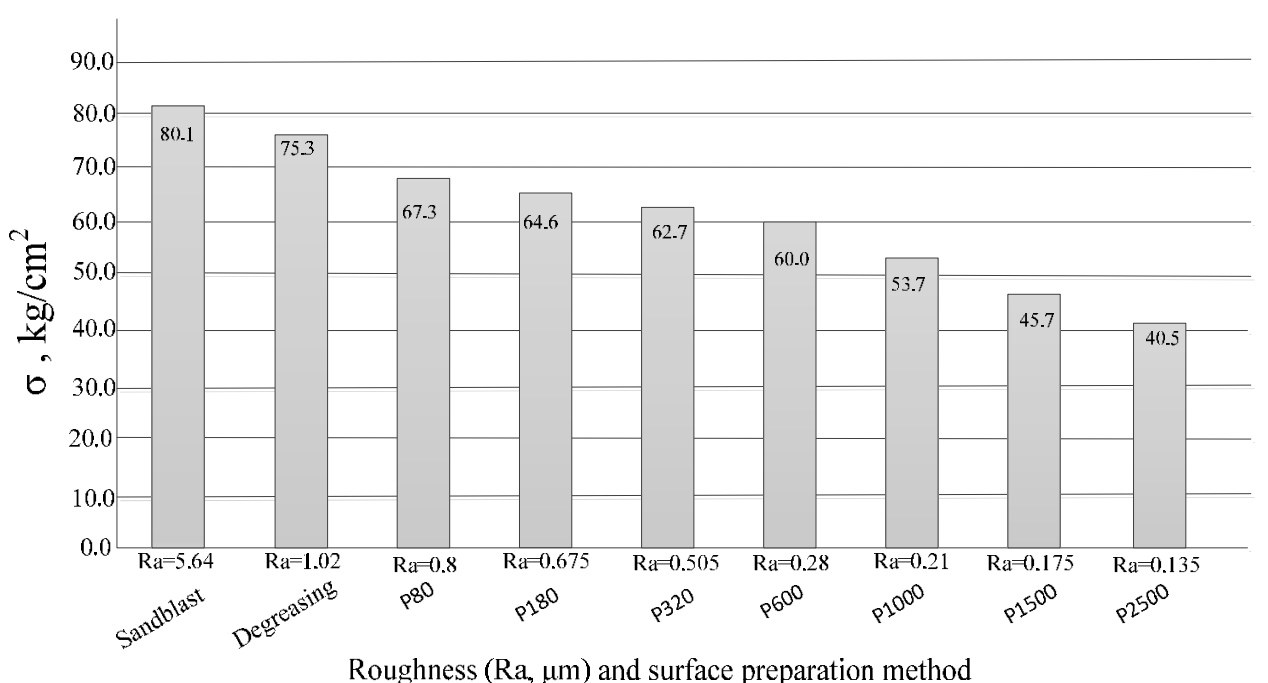

Fig. 9. Roughness dependence of the adhesion strength of coatings with a base obtained in $\mathrm{Na}_{2} \mathrm{HPO}_{4}$ electrolyte

Рис. 9. Зависимость адгезионной прочности покрытий с основой, полученных в электролите $\mathrm{Na}_{2} \mathrm{HPO}_{4}$, от шероховатости

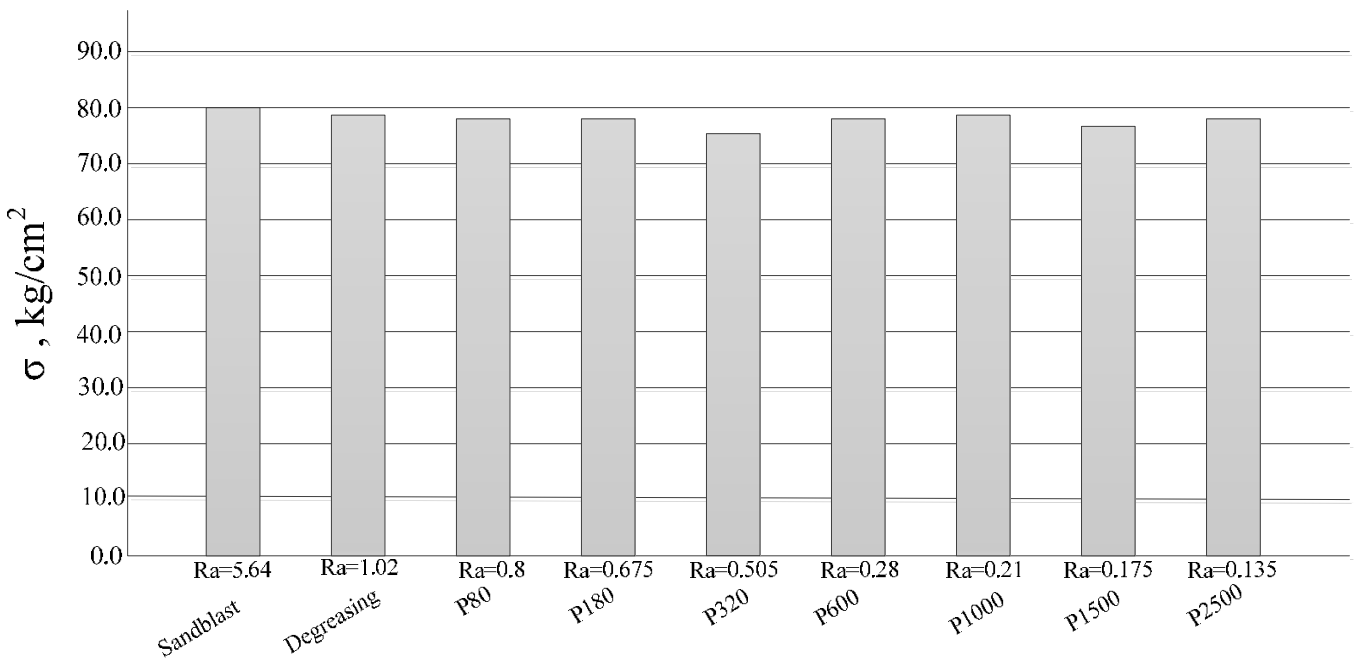

Roughness (Ra, $\mu \mathrm{m})$ and surface preparation method

Fig. 10. Roughness dependence of the adhesion strength of coatings with a base obtained in $\mathrm{KOH}+\mathrm{Na}_{2} \mathrm{SiO}_{3}$ electrolyte

Рис. 10. Зависимость адгезионной прочности покрытий с основой, полученных в электролите $\mathrm{KOH}+\mathrm{Na}_{2} \mathrm{SiO}_{3}$, от шероховатости

The data obtained show that the adhesion strength of coatings to the base obtained in the $\mathrm{KOH}+\mathrm{Na}_{2} \mathrm{SiO}_{3}$ electrolyte exceeds the strength of $\mathrm{VK} 3 / \mathrm{BK} 3$ glue. Therefore, to determine the actual adhesion strength, it is necessary to conduct additional studies using a higherstrength adhesive or other methods of measuring adhesive strength.

Conclusion. By a process of the conducted work, it was found that preliminary surface preparation of titanium alloys affects the characteristics of MAO coatings.

Based on the results obtained, it was concluded that in order to achieve the highest adhesive strength of the coating, it is necessary to perform MAO treatment at a ratio of
$I_{k} / I_{a}=1,2$ and at $I_{k} / I_{a}=0,8$ to obtain the maximum coating thickness.

Preliminary surface preparation affects the thickness and adhesive strength of coatings. With increase in roughness the adhesive strength increases and the thickness of the coating decreases.

Furthermore, based on the results obtained when measuring the adhesion strength of coatings with a base obtained in $\mathrm{KOH}+\mathrm{Na}_{2} \mathrm{SiO}_{3}$ electrolyte using VK 3/ BK 3 glue, the true strength has not been established. Therefore, it is necessary to conduct additional studies using a higher-strength adhesive or another method of measuring adhesive strength. 


\section{References}

1. Kolomeychenko A. V. Tekhnologii povysheniya dolgovechnosti detaley mashin vosstanovleniem $i$ uprochneniem rabochikh poverkhnostey kombinirovannymi metodami s primeneniem mikrodugovogo oksidirovaniya [Technologies for increasing the durability of machine parts by restoration and hardening of working surfaces by combined methods using microarc oxidation]. Orel, Izd-vo Orel GAU Publ., 2013, 255 p.

2. Zhukov S. V. Issledovanie protsessov i razrabotka tekhnologii formirovaniya mnogofunktsional'nykh pokrytiy MDO na titanovykh splavakh v priborostroenii. Kand. Diss. [Investigation of the processes of formation and development of the technology of multifunctional coatings on titanium alloys MDO in instrument. Cand. Diss.]. Moscow, 2009.

3. Suminov I. V. et al. Mikrodugovoe oksidirovanie (teoriya, tekhnologiya, oborudovanie) [Microarc oxidation (theory, technology, equipment)]. Moscow, EKOMET Publ., 2005, 368 p.

4. Gordienko P. S., Gnedenkov S. V. Mikrodugovoe oksidirovanie titana $i$ ego splavov [Microarc oxidation of titanium and its alloys].Vladivostok, Dal'nauka Publ., 1997, $185 \mathrm{p}$.

5. Girn A. V., Vakhteev E. V., Trushkina T. V., Orlova D. V. [The influence of technological parameters of micro-arc oxidation on the corrosion resistance of coatings]. Miass. Mekhanika i protsessy upravleniya. Materialy XXXXI Vserossiyskogo simpoziuma. Vol. 3. Moscow, RAN Publ., 2011, P. 168-173 (In Russ.).

6. Trushkina T. V., Girn A. V. [The corrosion resistance of MAO coatings in aggressive environments]. Vestnik SibGAU. 2014, Vol. 1(53), P. 179-184 (In Russ.).

7. Mamaev A. I., Dorofeeva T. I., Mamaeva V. A., Borikov V. N. [Adhesion and plasticity of coatings obtained by microplasma oxidation of titanium]. Tekhnologiya materialov. 2008, No. 3, P. 33-37 (In Russ.).

8. Mamaev, A.I., Mamaeva, V.A. Sil'notokovye mikroplazmennye protsessy $v$ rastvorakh elektrolitov [High current microplasma processes in electrolyte solutions]. Novosibirsk, Izdatel'stvo SO RAN, 2005, 255 p.

9. Gordienko P. S., Vasilenko V. S. [Formation of coatings on valve metals and alloys in electrolytes with a capacitive energy regulation at microarc oxidation]. Zashchita metallov. 2006, Vol. 42, No. 5, P. 500-505 (In Russ.).

10. Mamaev A. I., Mamaeva V. A., Borikov V. N., Dorofeeva T. I. Formirovanie nanostrukturnykh nemetallicheskikh neorganicheskikh pokrytiy putem lokalizatsii vysokoenergeticheskikh potokov na granitse razdela faz [Formation of nanostructured inorganic non-metallic coatings by the localization of high-energy fluxes at the interface]. Tomsk, Izd-vo Tom. un-ta Publ., 2010, 360 p.

11. Suminov I. V. Plazmenno-elektroliticheskoe modifitsirovanie poverkhnosti metal-lov $i$ splavov [Plasmaelectrolytic surface modification of metals and alloys]. Moscow, TEKhNOSFERA Publ., 2011, 512 p.

12. Terekhin N. A., Statsura V. V., Golenkova A. A., Ivasev S. S., Girn A. V. [Technological capabilities of micro-arc oxidation of aluminum alloys]. Vestnik mashinostroeniya. 2003, No. 2, P. 56-63 (In Russ.).
13. Andreev A. S. [The effect of the electrolyte composition on the structure with the properties of oxide coatings formed on titanium alloys by microarc oxidation]. Reshetnevskie chteniya: materialy XIII Mezhdunar. nauch. konf., posvyashch. pamyati general. konstruktora ra-ket.-kosmich. sistem akademika M. F. Reshetneva [Reshetnev readings. Materials of the XIII International scientific Conf. memory of the general. the designer of rockets. systems of academician M. F. Reshetnev]. Krasnoyarsk, 2009. Ch. 1. P. 307-308 (In Russ.).

14. Rudnev V. S. et al. Sposob mikrodugovogo oksidirovaniya ventil'nykh metallov $i$ ikh splavov [A method of micro-arc oxidation of valve metals and their alloys]. Patent RF, no 1783004, 1992.

15. Gordienko P. S. Obrazovanie pokrytiy na anodnopolyarizovannykh elektrodakh $v$ vodnykh elektrolitakh pri potentsialakh iskreniya i proboya [Forming a coating on the anode-polarized electrodes in aqueous electrolytes at potentials sparking and breakdown]. Vladivostok, Dal'nauka Publ., 1996, 216 p.

16. Fedorov V. A. et al. [Formation of hardened surface layers by micro-arc oxidation in various electrolytes and when changing current modes]. Fizika $i$ khimiya obrabotki materialov. 1991, No. 1, P. 87-93 (In Russ.).

17. Nechaev G. G. [Microarc oxidation of titanium alloys in alkaline electrolytes]. Kondensirovannye sredy $i$ mezhfaznye granitsy. 2012, Vol. 14, No 4, P. 453-455 (In Russ.).

18. Kuznetsov Yu. A., Kulakov K. V., Goncharenko V. V. Osobennosti vybora elektrolita dlya polucheniya tolstosloynykh keramicheskikh pokrytiy [Features choice of electrolyte to produce thick ceramic coatings] (In Russ.). Available at: http://science-bsea.narod.ru/ 2011/mashin_2011_14/kuznecov texno.htm (accessed: 20.12.2019).

19. Gordienko P. S., Gnedenko S. V., Khrisanfova O. A., Vostrikova N. G., Kovryakov A. N. Elektrolit dlya formirovaniya pokrytiy na ventil'nykh metallakh [The electrolyte for forming coatings on valve metals]. Patent RF, no. 2046156, 1995.

20. GOST 209-75. Rezina i kley. Metody opredeleniya prochnosti svyazi s metallom pri otryve [State Standard 209-75. Rubber and glue. Methods for determining the bond strength with metal upon separation]. Moscow, Publishing house of standards, 1993. 23 p.

\section{Библиографические ссылки}

1. Коломейченко А. В. Технологии повышения долговечности деталей машин восстановлением и упрочнением рабочих поверхностей комбинированными методами с применением микродугового оксидирования : монография. Орел : Орел ГАУ, 2013. 255 с.

2. Жуков С. В. Исследование процессов и разработка технологии формирования многофункциональных покрытий МДО на титановых сплавах в приборостроении : автореф. дис. ... канд. техн. наук. М. : МАТИ - Российский государственный технологический университет им. К. Э. Циолковского, 2009.

3. Микродуговое оксидирование (теория, технология, оборудование) / И. В. Суминов и др. М. : ЭКОМЕТ, 2005. $368 \mathrm{c}$. 
4. Гордиенко П. С., Гнеденков С. В. Микродуговое оксидирование титана и его сплавов. Владивосток : Дальнаука, 1997. 185 с.

5. Влияние технологических параметров микродугового оксидирования на коррозионную стойкость покрытий / А. В. Гирн, Е. В. Вахтеев, Т. В. Трушкина, Д. В. Орлова // Миасс. Механика и процессы управления : материалы XXXXI Bcepocc. симп. Т. 3. М. : PAH, 2011. C. 168-173.

6. Трушкина Т. В., Гирн А. В. Коррозионная стойкость МДО покрытий в агрессивных средах // Вестник СибГАУ. 2014. № 1(53). С. 179-184.

7. Адгезия и пластичность покрытий, полученных микроплазменным оксидированием титана / А. И. Мамаев, Т. И. Дорофеева, В. А. Мамаева, В. Н. Бориков // Технология материалов. 2008. № 3. С. 33-37.

8. Мамаев А. И., Мамаева В. А. Сильнотоковые микроплазменные процессы в растворах электролитов. Новосибирск : Изд-во СО РАН, 2005. 255 с.

9. Формирование покрытий на вентильных металлах и сплавах в электролитах с емкостным регулированием энергии при микродуговом оксидировании / П. С. Гордиенко, В. С. Василенко и др. // Защита металлов. 2006. Т. 42, № 5. С. 500-505.

10. Формирование наноструктурных неметаллических неорганических покрытий путем локализации высокоэнергетических потоков на границе раздела фаз / А. И. Мамаев, В. А. Мамаева, В. Н. Бориков, Т. И. Дорофеева. Томск : Изд-во Том. ун-та, 2010. 360 с.

11. Суминов И. В. Плазменно-электролитическое модифицирование поверхности металлов и сплавов. М. : Техносфера, 2011. 512 c.

12. Технологические возможности микродугового оксидирования алюминиевых сплавов / Н. А. Терехин, В. В. Стацура, А. А. Голенкова и др. // Вестник машиностроения. 2003. № 2. С. 56-63.

13. Андреев А. С. Влияние состава электролита на структуру с свойства оксидных покрытий, сформированных на титановых сплавах микродуговым оксидированием // Решетневские чтения : материалы XIII Междунар. науч. конф., посвящ. памяти генерал. конструктора ракет.-космич. систем акад. М. Ф. Решетнева (10-12 ноября 2009, г. Красноярск) : в 2 ч. / под общ. ред. Ю. Ю. Логинова ; Сиб. гос. аэрокосмич. ун-т. Красноярск, 2009. Ч. 1. С. 307-308.

14. Патент России 1783004, МКИ5 C25D11/02. Способ микродугового оксидирования вентильных металлов и их сплавов / В. С. Руднев, П. С. Гордиенко, А. Г. Курносова, Т. И. Орлова ; заявл. 17.10.89 ; опубл. 23.12.92, Бюл. № 47.

15. Гордиенко П. С. Образование покрытий на анодно-поляризованных электродах в водных электролитах при потенциалах искрения и пробоя. Владивосток : Дальнаука, 1996. 216 с.

16. Федоров В. А., Белозеров В. В., Великосельская Н. Д. Формирование упрочненных поверхностных слоев методом микродугового оксидирования в различных электролитах и при изменении токовых режимов // Физика и химия обработки материалов. 1991. № 1. С. 87-93.

17. Нечаев Г. Г. Микродуговое оксидирование титановых сплавов в щелочных электролитах // Конденсированные среды и межфазные границы. 2012. T. 14, № 4. С. 453-455.

18. Кузнецов Ю. А., Кулаков К. В., Гончаренко В. В. Особенности выбора электролита для получения толстослойных керамических покрытий [Электронный pecypc]. URL: http://science-bsea.narod.ru/2011/mashin 2011_14/kuznecov_texno.htm (дата обращения: 20.12.2019).

19. Патент РФ 2046156, МПК6 C25D11/04. Электролит для формирования покрытий на вентильных металлах / П. С. Гордиенко, С. В. Гнеденко, О. А. Хрисанфова, Н. Г. Вострикова, А. Н. Ковряков ; заявл. 21.05.92 ; опубл. 20.10.95 ; заявка № 5043332/26.

20. ГОСТ 209-75. Резина и клей. Методы определения прочности связи с металлом при отрыве. М. : Изд-во стандартов, 1993. 23 с.

(c) Mikheev A. E., Girn A. V., Ravodina D. V., Elizar'eva I. G., 2020

Miheev Anatolii Egorovich - Dr. Sc., Professor; Reshetnev Siberian State University of Science and Technology. E-mail:michla@mail.ru.

Girn Aleksei Vasilyevich - Cand. Sc., associate professor; Reshetnev Siberian State University of Science and Technology. E-mail: girn007@gmail.com.

Ravodin Daria Vladimirovna - engineer; Reshetnev Siberian State University of Science and Technology. E-mail: Dashaorlova12@yandex.ru.

Elizarieva Irina Georgievna - undergraduate; Reshetnev Siberian State University of Science and Technology. E-mail: elirina777@mail.ru.

Михеев Анатолий Егорович - доктор технических наук, профессор, заведующий кафедрой летательных аппаратов, Сибирский государственный университет науки и технологий имени академика М. Ф. Решетнёва. E-mail: michla@mail.ru.

Гирн Алексей Васильевич - кандидат технических наук, доцент, доцент кафедры летательных аппаратов, Сибирский государственный университет науки и технологий имени академика М. Ф. Решетнёва. Е-mail: girn007@gmail.com.

Раводина Дарья Владимировна - инженер, Сибирский государственный университет науки и технологий имени академика М. Ф. Решетнёва. E-mail: Dashaorlova12@yandex.ru.

Елизарьева Ирина Георгиевна - магистрант, Сибирский государственный университет науки и технологий имени академика М. Ф. Решетнёва. E-mail: elirina777@mail.ru. 